\title{
MICROCLIMATE EFFECTS ON NUMBER AND DISTRIBUTION OF FUNGI IN THE WLODARZ UNDERGROUND COMPLEX IN THE OWL MOUNTAINS (GÓRY SOWIE), POLAND
}

\author{
Rafal Ogórek ${ }^{1}$, Wojciech Pusz ${ }^{*}$, Agnieszka Lejman², and Cecylia Uklańska-PusZ ${ }^{3}$
}

\begin{abstract}
In July 2013 we studied the occurrence of fungi in an underground complex named Włodarz, located inside the massif of Włodarz, within the Owl Mountains, Lower Silesia, Poland. The study is the first mycological evaluation of the rocks in the Włodarz underground complex and the air inside and outside of it. To examine the air, the Air Ideal 3P sampler and PDA medium were used. Microbiological evaluation of the rocks inside the adit was performed using two methods, swab sampling and rinse sampling. The results were analyzed by ANOVA, and means were compared using Fisher's least significant difference (LSD) test at $\alpha \leq 0.05$. Eleven taxa of filamentous fungi were isolated from the air sampled outside the Włodarz adit, and fifteen from the air inside. Between 65.5 and 1003 colony-forming units of fungi per $\mathrm{m}^{3}$ of air were isolated from the air sampled in the adit and about 1115 CFU from the air sampled outside of it; the differences are statistically significant. The majority of the airborne fungi were isolated from outside the adit and from the ventilation shaft containing a waterfall, probably due to air movement. From the rock walls of the shafts seven taxa of fungi were isolated, whereas from the rock debris on the adit's floor, only six taxa. The densities of fungi obtained from the research locations are statistically significant, and the most dense fungus isolated from the air outside and inside the adit was Cladosporium cladosporioides, followed by $C$. herbarum at one locations in the adit. Taxa of the Aspergillus niger group were most common on the rock debris and wall rocks except for one location where Penicillium chrysogenum was most common on the rock debris and one location where Cladosporium cladosporioides was most common from the rocks walls.
\end{abstract}

\section{INTRODUCTION}

The Włodarz underground complex is a system of adits and shafts constructed inside the upper part of the massif of Włodarz (in German, Wolfsberg), part of the Owl Mountains (Góry Sowie) in Central Sudetes, Lower Silesia, Poland. The complex is located within the northeastern slope of the massif. The mountain range extends in the Central Sudetes along a northwest-southeast axis, but from the point of view of geology and tectonics, the material is distinct and described as the Owl Mountains gneiss.

The Włodarz complex is one of the components of a tunnel complex code-named Riese constructed by the Nazis beginning in 1943. The location had been chosen for two main reasons. The area was located away from the front lines, and the strength of the rock and the stability of the mountains was adequate protection against possible air strikes. The tunnels were drilled using mining techniques; prisoners bored holes into the rock substrate that were then loaded with explosives. The workforce used were prisoners from the Nazi concentration camp Gross-Rosen. Currently the interior of the complex can only be accessed by one of the four existing tunnels. Of the remaining three, two tunnels are now flooded and collapsed (Fig. 1). It is assumed that the target number of tunnels was six, but no previous studies have confirmed the assumption. The entrances to the tunnels are located at an altitude between 585 and $590 \mathrm{~m} \mathrm{msl}$, and the tunnels run in the northeastsouthwest direction inside the top-most part of Włodarz Massif. The total length of the known and mapped excavations is about $3100 \mathrm{~m}$, with a total floor surface of approximately $10,710 \mathrm{~m}^{2}$ and a volume of $42,000 \mathrm{~m}^{3}$ (Kasza 2012). The Włodarz complex was opened for tourists beginning in 2004, with about forty thousand visitors a year, making it one of the most popular site for tourist visits in Lower Silesia.

The presence of tourists in caves and in other underground places is capable of changing the microclimate, the biogeochemistry, and the balance of organic matter in them. It may hence indirectly impact autochthonous microbial

\footnotetext{
* Corresponding Author: wojciech.pusz@up.wroc.pl

${ }^{1}$ Wrocław University of Environmental and Life Sciences, Department of Plant Protection, Division of Phytopathology and Mycology, pl. Grunwaldzki 24a, 50-363 Wrocław, Poland

${ }^{2}$ Wrocław University of Environmental and Life Sciences, Department of Agroecosystems and Green Areas Management

${ }^{3}$ Wrocław University of Environmental and Life Sciences, Department of Horticulture
} 


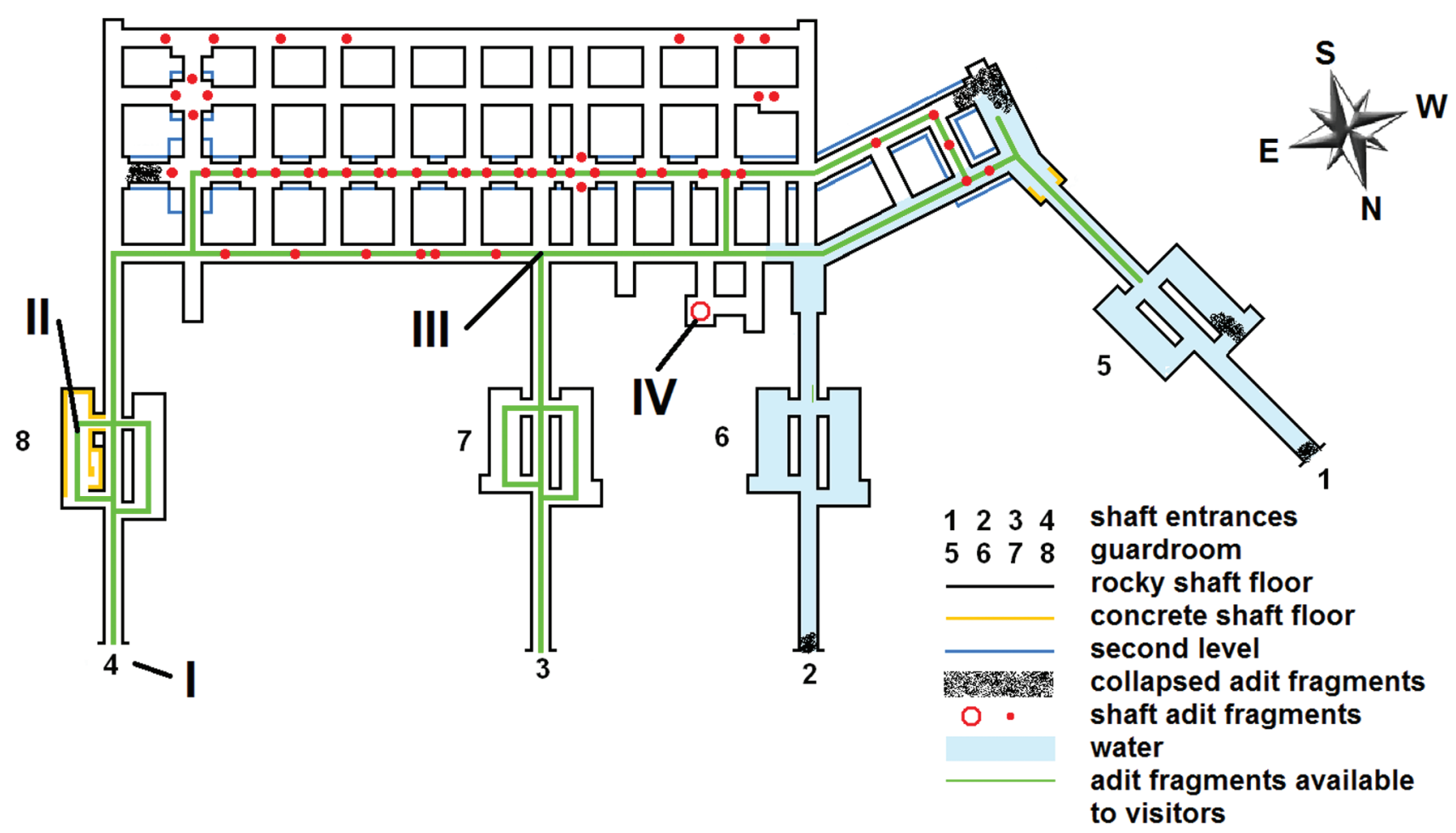

Figure 1. The plan, based on Kasra (2012), of the Włodarz underground complex of tunnels, with the sample locations indicated. I, the entrance; II, the guard house; III, the crossroads; and IV the ventilation shaft.

communities, such as those of fungi. Seen from that perspective, the visits are always undesirable, and therefore, the presence of microorganisms should be monitored in all cave and underground ecosystems. The identification of reservoirs of potentially pathogenic fungi and the elucidation of the distribution of these communities and their components are important not only in preventing potential health problems in tourists (Fernández-Cortés et al., 2011; Saíz-Jiménez, 2012), but also in maintaining the stability of any underground ecosystem. Fungi can be dangerous for humans and also affect the walls of caves and adits. In humans, they can cause infections and allergies. For example, Aspergillus spp. can cause aspergillosis of the lungs, sinuses, cornea, orbit, skin, nails, and ear canal. Rhizopus spp. can cause generalized mucormycosis, as well as infections of lungs and sinuses. Infection by Fusarium spp. can result in generalized fusariosis (Adamski et al., 2008). Fungi such as Fusarium spp. in caves and adits may cause biodeterioration of natural stones (Gu et al., 1998), and fungi such as Epicoccum spp. can contaminate stones with pigments ( $\mathrm{Li}$ et al., 2008).

Our research focused on two goals: 1) the mycological analysis of the species composition of the fungi found in the air inside and outside of the underground Włodarz complex and on rocks in it, and 2) to quantify their concentrations.

\section{Materials And Methods}

The air samples were taken on July 5, 2013 from one location outside the adit (near entrance 4, sample location I in Fig. 1) and from three locations inside it, the guard house (II), the crossing (III), and the ventilation shaft (IV). The air temperature and relative humidity were measured using a thermohygrometer LB-522 (LAB-EL). The carbon dioxide concentration was measured using a $\mathrm{CO}_{2}$ meter pSense RH (Gazex). Moisture content of rocks was measured with the Testo 606-1 (Testo) hygrometer, and the wind speed by aerometer Testo 410-1 (Testo).

\section{Media}

The following growth media were used: Potato Dextrose Agar (PDA, Biocorp), Czapek-Dox Agar (1.2\% agar, Biocorp) and Malt Extract Agar (MEA, Biocorp). PDA medium was used for the isolation of fungi from the air and the rocks and for the identification of some species. Czapek-Dox agar medium and MEA medium were used for identification of the fungi of Penicillium and Aspergillus genera.

\section{Fungal IDENTIFICATION}

The fungal colonies grown on all the Petri dishes were counted and identified. The specific identification of the sampled fungi was performed using macro- and microscopic 
Microclimate efFects on Number ANd distribution of Fungi in the Włodarz underground COMPLEX In the Owl Mountains (Góry Sowie), Poland

Table 1. Microclimate conditions in the Włodarz underground complex on July 5, 2013.

\begin{tabular}{|c|c|c|c|c|c|c|}
\hline \multirow[b]{2}{*}{ Measurement Location } & \multicolumn{2}{|c|}{ Air } & \multirow[b]{2}{*}{$\begin{array}{l}\text { Wind Speed, } \\
\mathrm{m} \mathrm{s}^{-1}\end{array}$} & \multirow[b]{2}{*}{$\mathrm{CO}_{2}, \mathrm{ppm}$} & \multicolumn{2}{|c|}{ Moisture Content, \% } \\
\hline & $\begin{array}{l}\text { Temperature, } \\
{ }^{\circ} \mathrm{C}\end{array}$ & $\begin{array}{c}\text { Relative } \\
\text { Humitidy, \% }\end{array}$ & & & $\begin{array}{l}\text { Rock } \\
\text { Wall }\end{array}$ & $\begin{array}{l}\text { Rock } \\
\text { Debris }\end{array}$ \\
\hline Near the entrance (Site I) & 24.6 & 50.2 & 0.8 & 390.0 & $\ldots$ & $\ldots$ \\
\hline Guard-house (Site II) & 11.0 & 61.4 & 0.0 & 560.0 & 39.4 & 21.2 \\
\hline Crossroads (Site III) & 10.6 & 67.4 & 0.0 & 608.0 & 36.0 & 21.0 \\
\hline $\begin{array}{l}\text { Ventilation shaft with waterfall } \\
\text { (Site IV) }\end{array}$ & 12.8 & 98.0 & 0.2 & 400.0 & 39.9 & 32.1 \\
\hline
\end{tabular}

observations of hyphae, conidia, and sporangia and colony morphology according to the commonly accepted methods used in mycological laboratories. The fungi were identified using diagnostic keys (Raper and Fennell 1965; Raper and Thom 1968; Ellis 1971; Zycha and Siepmann 1973; Arx 1974).

\section{Mycological Evaluation of the Air}

We used PDA medium to examine the fungal load of air. The sampler (Air Ideal 3P) was programmed for air sample volumes of $50 \mathrm{~L}, 100 \mathrm{~L}$, and $150 \mathrm{~L}$. Measurements in each location were performed in six replicates for each volume. The sampler was positioned $1.5 \mathrm{~m}$ above the level of the cave floor. The incubation of the cultures was carried out at room temperature $\left(22{ }^{\circ} \mathrm{C}\right)$ for 2 to 7 days, in darkness. After the incubation, the fungi were identified and the numbers of colony forming units per $\mathrm{m}^{3}$ of air were calculated.

\section{Mycological Evaluation of the Rocks}

Mycological evaluation of the rocks inside the adits was performed using two methods, swabbing of the wall and rinsing of rock debris.

At sample locations II, III, and IV inside the complex (Fig. 1) swabs of the wall were made using sterile swabs in transport tubes (sterile $15 \mathrm{~cm}$ viscose swab). Material from every location was sampled with three swabs from a surface area of $1 \mathrm{~cm}^{2}$. The samples were taken from the cave walls at the height of $1.5 \mathrm{~m}$ above the floor. On the same day, the collected samples were shaken for 20 minutes in 50-ml Erlenmayer flasks containing $10 \mathrm{ml}$ of sterile water. After shaking, the samples were placed in Petri dishes onto the PDA agar using serial dilution. The incubation of cultures was at room temperature $\left(22{ }^{\circ} \mathrm{C}\right)$ in darkness, for 2 to 7 days. After incubation, the fungi were identified and the numbers of CFU per $\mathrm{cm}^{2}$ of rock surface were calculated.

At sampling locations II, III, and IV (Fig. 1), four samples of rock debris from the floor were collected in sterile sampling bags (114 by $229 \mathrm{~mm}$ ). On the same day, each sample (ca. $50 \mathrm{~g}$ ) was shaken for 20 minutes in a 250 $\mathrm{mL}$ Erlenmeyer flask containing $100 \mathrm{~mL}$ of sterile water. After shaking, the samples were plated onto PDA agar using serial dilution. The incubation of cultures was for 2 to 7 days. After the incubation, the fungal taxa were identified and the numbers of CFU per $50 \mathrm{~g}$ of rock debris were calculated.

\section{Statistical Analysis}

The results were analyzed by ANOVA, using Statistica 9.0 package. Means were compared using Fisher's leastsignificant-difference test at $\alpha \leq 0.05$.

\section{RESULTS}

The results of the environmental measurements are in Table 1. The air temperature during the study in Włodarz complex was $24.6{ }^{\circ} \mathrm{C}$ outside the adit and approximately $11{ }^{\circ} \mathrm{C}$ inside it. The wind at the entrance (Site I) was $0.8 \mathrm{~m} \mathrm{~s}^{-1}$. Inside air movement was only observed at the ventilation shaft with the waterfall (Site IV), and there it was only $0.2 \mathrm{~m} \mathrm{~s}^{-1}$. The highest concentration of carbon dioxide was observed inside the adit at Site III, and the lowest was at the entrance. Rock moisture was higher in wall rock than in debris on the adit's floor.

Eleven taxa of filamentous fungi were cultured from the air sampled outside the Włodarz complex and fifteen from the inside air. From the rock walls we cultured seven taxa of fungi, but only six taxa from the floor debris. Aspergillus niger group and Mucor spp. were present only on the rock, whereas Acremonium strictum, Alternaria alternata, Botrytis cinerea, Cladosporium herbarum, Epicoccum nigrum, Fusarium avenaceum, Fusarium equiseti, Penicillium citrinum, Penicillium waksmanii, Sordaria fimicola, and Ulocladium alternariae were found exclusively in the air (Table 2).

The quantities of filamentous fungi taxa isolated from the air inside and outside the Włodarz adit ranged between 65.5 to 1115.9 colony forming units per $\mathrm{m}^{3}$ of air (Table 3 ). The most taxa of filamentous fungi were isolated from the air outside the complex, whereas from the air inside, the highest number of species were isolated from the ventilation shaft with waterfall (Site IV) and the smallest number of species from this group was observed in the guard house (Table 3). The highest density of colonies, both from the rock walls and from the rock debris on the adit's floor, were cultured from the ventilation shaft with waterfall (Tables 4 and 5). The smallest number of CFU was 
R. Ogórek, W. Pusz, A. Lejman, and C. Uklańska-Pusz

Table 2. Species of filamentous fungi cultured from the outside and inside air and from the rocks in the Włodarz complex. A + indicates the species was found.

\begin{tabular}{|c|c|c|c|c|c|}
\hline \multirow[b]{2}{*}{ Taxa } & & \multicolumn{2}{|c|}{ Air } & \multicolumn{2}{|c|}{ Rock } \\
\hline & & Outside & Inside & Wall & Debris \\
\hline 1 & Aspergillus niger group & - & - & + & + \\
\hline 2 & Acremonium strictum & + & - & - & - \\
\hline 3 & Alternaria alternata & + & - & - & - \\
\hline 4 & Botrytis cinerea & - & + & - & - \\
\hline 5 & Cladosporium cladosporioides & + & + & + & + \\
\hline 6 & Cladosporium herbarum & + & + & - & - \\
\hline 7 & Epicoccum nigrum & + & + & - & - \\
\hline 8 & Fusarium avenaceum & - & + & - & - \\
\hline 9 & Fusarium culmorum & - & + & + & - \\
\hline 10 & Fusarium equiseti & + & - & - & - \\
\hline 11 & Fusarium oxysporum & + & + & + & - \\
\hline 12 & Мисоr spp. & - & - & + & + \\
\hline 13 & Penicillium chrysogenum & - & + & - & + \\
\hline 14 & Penicillium citrinum & + & + & - & - \\
\hline 15 & Penicillium expansum & - & + & + & - \\
\hline 16 & Penicillium waksmanii & - & + & - & - \\
\hline 17 & Rhizopus spp. & + & + & + & + \\
\hline 18 & Sclerotinia sclerotiorum & - & + & - & + \\
\hline 19 & Sordaria fimicola & + & + & - & - \\
\hline 20 & Ulocladium alternariae & + & + & - & - \\
\hline$\Sigma$ species & & 11 & 15 & 7 & 6 \\
\hline
\end{tabular}

observed in the guard house for rock debris, while for rock wall both the guard house and the crossroads sites were smallest and statistically similar. (Tables 4 and 5).

The fungus most frequently cultured from the air outside and inside the adit was Cladosporium cladosporioides, except in the guard house, where $C$. herbarum was most common. The least common fungus species in the outside air was Acremonium strictum, but the abundance of this species do not differ significantly from that of six other species. The species Epicoccum nigrum, Fusarium culmorum, Penicillium citrinum, Sclerotinia sclerotiorum, and Ulocladium alternariae were the least common in the guard house, $F$. culmorum was least common in the crossroads samples, and $F$. culmorum and $F$. oxysporum were least common at the ventilation shaft site (Table 3).

The species most common in cultured from the rock walls and the rocky debris was the Aspergillus niger group in the guard house and crossroads locations, while at the ventilation shaft Cladosporium cladosporioides was most common on the rock walls and Penicillium chrysogenum in rocky floor debris (Tables 4 and 5).

\section{DisCusSion}

The total numbers of fungi cultured from the air at the various sampling sites differed significantly (Table 3 ). The most airborne fungi were found outside the complex (Site I in Fig. 1) and in the ventilation shaft with waterfall (Site IV). The situation is probably due to the air movement at those locations (Table 1). Moreover, the complex is populated by bat colonies and accessible to tourism (Martini, 1963; Shapiro and Pringle, 2010; Porca et al., 2011; Ogórek et al., 2013). Mulec (2008) reported that microbes are passively transported by airflows, which depend on the season and represent an important mode of spreading inoculum to different parts of caves. Dripping and seeping water, as in the Włodarz complex at the ventilation shaft, may be another carrier of microbes. Hsu and Agoramoorthy (2001), Kuzmina et al. (2012), and Mulec et al. (2012) noted that microorganisms show decreasing biodiversity and biomass starting from the entrance towards the deep zones in caves, a gradient that they found very important for survival and development of fungi.

According to Nieves-Rivera (2003), Nováková (2009), and Vanderwolf et al. (2013), the most abundant fungi in caves are Aspergillus, Penicillium, Mucor, Fusarium, Trichoderma, and those of Cladosporium genus. Our results agree with theirs. The most common airborne fungi in the Włodarz complex were Cladosporium from air, Aspergillus and Cladosporium from rock walls, and Aspergillus and Penicillium from rocky debris. These results were statistically significant. The work of other researchers surveying caves with respect to fungal spores supports these findings.

Journal of Cave and Karst Studies, August 2014•149 
Microclimate efFects on Number ANd distribution of Fungi in the Włodarz underground COMPLEX In the Owl Mountains (Góry Sowie), Poland

Table 3. Filamentous fungi cultured from the air at the Włodarz underground complex, with means of colony forming units per $\mathrm{m}^{3}$ for six replicated air samples.

\begin{tabular}{|c|c|c|c|c|}
\hline \multirow{3}{*}{$\frac{\text { Sampling Location }}{\text { Near Entrance (Site I) }}$} & \multicolumn{2}{|c|}{ Taxa } & \multirow{2}{*}{\multicolumn{2}{|c|}{$\operatorname{Air}\left(\mathrm{CFU} / \mathrm{m}^{3}\right)$}} \\
\hline & \multirow{2}{*}{$\begin{array}{c}\text { Name } \\
\text { Alternaria alternata }\end{array}$} & \multirow{2}{*}{$\begin{array}{c}\text { Percent } \\
0.3\end{array}$} & & \\
\hline & & & 3.3 & $\mathrm{~d}$ \\
\hline & Acremonium strictum & 0.3 & 3.1 & $\mathrm{~d}$ \\
\hline & Botrytis cinerea & 29.8 & 333.0 & $\mathrm{~b}$ \\
\hline & Cladosporium cladosporioides & 58.2 & 650.0 & $\mathrm{a}$ \\
\hline & Cladosporium herbarum & 3.6 & 40.0 & $\mathrm{c}$ \\
\hline & Epicoccum nigrum & 0.6 & 6.7 & $\mathrm{~d}$ \\
\hline & Fusarium equiseti & 0.3 & 3.0 & $\mathrm{~d}$ \\
\hline & Fusarium oxysporum & 0.6 & 6.7 & $\mathrm{~d}$ \\
\hline & Penicillium citrinum & 2.1 & 23.3 & $\mathrm{~cd}$ \\
\hline & Rhizopus spp. & 3.0 & 33.0 & $\mathrm{c}$ \\
\hline & Sclerotinia sclerotiorum & 0.6 & 6.7 & $\mathrm{~d}$ \\
\hline & Ulocladium alternariae & 0.6 & 7.1 & $\mathrm{~d}$ \\
\hline & & & 1115.9 & A \\
\hline Guard House (Site II) & Cladosporium cladosporioides & 8.1 & 5.3 & $\mathrm{~d}$ \\
\hline & Cladosporium herbarum & 42.6 & 28.0 & $\mathrm{a}$ \\
\hline & Epicoccum nigrum & 2.3 & 1.5 & $\mathrm{e}$ \\
\hline & Fusarium culmorum & 2.0 & 1.3 & $\mathrm{e}$ \\
\hline & Penicillium chrysogenum & 12.2 & 8.0 & $\mathrm{~b}$ \\
\hline & Penicillium citrinum & 1.7 & 1.1 & $\mathrm{e}$ \\
\hline & Penicillium expansum & 8.1 & 5.3 & $\mathrm{~d}$ \\
\hline & Penicillium waksmanii & 10.2 & 6.7 & $\mathrm{c}$ \\
\hline & Rhizopus spp. & 8.4 & 5.5 & $\mathrm{~cd}$ \\
\hline & Sclerotinia sclerotiorum & 2.0 & 1.3 & $\mathrm{e}$ \\
\hline & Ulocladium alternariae & 2.4 & 1.6 & $\mathrm{e}$ \\
\hline & & & 65.5 & $\mathrm{D}$ \\
\hline Crossroads (Site III) & Cladosporium cladosporioides & 33.8 & 25.0 & $\mathrm{a}$ \\
\hline & Cladosporium herbarum & 19.6 & 14.4 & $\mathrm{c}$ \\
\hline & Fusarium culmorum & 1.5 & 1.1 & f \\
\hline & Penicillium chrysogenum & 6.8 & 5.0 & $\mathrm{e}$ \\
\hline & Penicillium citrinum & 7.5 & 5.6 & $\mathrm{e}$ \\
\hline & Penicillium expansum & 21.8 & 16.1 & $\mathrm{~b}$ \\
\hline & Sclerotinia sclerotiorum & 9.0 & 6.7 & $\mathrm{~d}$ \\
\hline & & & 73.9 & $\mathrm{~B}$ \\
\hline Ventilation Shaft with & Botrytis cinerea & 1.1 & 11.0 & $\mathrm{e}$ \\
\hline Waterfall (Site IV) & Cladosporium cladosporioides & 84.8 & 851.0 & $\mathrm{a}$ \\
\hline & Cladosporium herbarum & 6.0 & 60.0 & $\mathrm{~b}$ \\
\hline & Epicoccum nigrum & 0.7 & 6.7 & $\mathrm{fg}$ \\
\hline & Fusarium avenaceum & 0.5 & 5.1 & $\mathrm{gh}$ \\
\hline & Fusarium culmorum & 0.3 & 3.0 & $\mathrm{~h}$ \\
\hline & Fusarium oxysporum & 0.3 & 3.3 & $\mathrm{~h}$ \\
\hline & Penicillium expansum & 2.0 & 20.0 & $\mathrm{~d}$ \\
\hline & Sclerotinia sclerotiorum & 3.3 & 33.3 & $\mathrm{c}$ \\
\hline & Sordaria fimicola & 1.0 & 9.6 & ef \\
\hline & & & 1003.0 & $\mathrm{C}$ \\
\hline
\end{tabular}

For each location, concentrations followed by the same letter are not statistically different at the $\alpha \leq 0.05$ level according to Fisher's least-significant-difference test; others are. Small letters mark the effect of locations on isolates taxa fungi. Capital letters mark the effect of a particular location on total fungal isolates. 
Table 4. Filamentous fungi cultured from swab sampling the wall rock in the Włodarz undergound complex, means of three replicate samples.

\begin{tabular}{|c|c|c|c|c|}
\hline \multirow{3}{*}{$\frac{\text { Sampling Location }}{\text { Guard-House (Site II) }}$} & \multicolumn{2}{|c|}{ Taxa } & \multirow{2}{*}{\multicolumn{2}{|c|}{$\begin{array}{l}\text { Rock Surface } \\
\left(\mathrm{CFU} / \mathrm{cm}^{3}\right)\end{array}$}} \\
\hline & \multirow{7}{*}{$\begin{array}{l}\text { Name } \\
\text { Aspergillus niger group } \\
\text { Cladosporium cladosporioides } \\
\text { Mucor spp. } \\
\text { Penicillium chrysogenum } \\
\text { Rhizopus spp. }\end{array}$} & \multirow{2}{*}{$\begin{array}{c}\text { Percent } \\
42.8\end{array}$} & & \\
\hline & & & 43.7 & a \\
\hline & & 9.2 & 9.4 & d \\
\hline & & 22.9 & 23.4 & $\mathrm{~b}$ \\
\hline & & 5.5 & 5.6 & $\mathrm{e}$ \\
\hline & & 19.7 & 20.1 & $\mathrm{c}$ \\
\hline & & & $102.2 \mathrm{~B}$ & B \\
\hline \multirow[t]{4}{*}{ Crossroads (Site III) } & Aspergillus niger group & 55.4 & 57.3 & a \\
\hline & Mucor spp. & 20.7 & 21.4 & $\mathrm{c}$ \\
\hline & Rhizopus spp. & 23.9 & 24.7 & $\mathrm{~b}$ \\
\hline & & & 103.4 & B \\
\hline Ventilation Shaft with & Aspergillus niger group & 14.0 & 25.0 & $\mathrm{c}$ \\
\hline \multirow[t]{7}{*}{ Waterfall (Site IV) } & Cladosporium cladosporioides & 37.1 & 66.0 & $\mathrm{a}$ \\
\hline & Fusarium culmorum & 6.2 & 11.0 & $\mathrm{f}$ \\
\hline & Fusarium oxysporum & 4.5 & 8.0 & g \\
\hline & Mucor spp. & 16.3 & 29.0 & $\mathrm{~b}$ \\
\hline & Penicillium expansum & 9.6 & 17.0 & e \\
\hline & Rhizopus spp. & 12.4 & 22.0 & $\mathrm{~d}$ \\
\hline & & & 178.0 & A \\
\hline
\end{tabular}

For each location, concentrations followed by the same letter are not statistically different at the $\alpha \leq 0.05$ level according to Fisher's least-significant-difference test; others are. Small letters mark the effect of locations on isolates taxa fungi. Capital letters mark the effect of a particular location on total fungal isolates.

A cave in Spain examined by Docampo et al. (2011) turned out to host several fungal species, with Penicillium and Cladosporium genera being the most numerous. Interestingly, in our air sampling both near the entrance and inside we found mostly the spores of Cladosporium at the Włodarz complex. Our results generally agree with those of Porca et al. (2011) and Fernández-Cortés et al. (2011). They claimed that the most abundant type of spore in the

Table 5. Filamentous fungi cultured from rinse sampling the floor rock debris in the Włodarz undergound complex, means of four replicate samples.

\begin{tabular}{|c|c|c|c|c|}
\hline \multirow{2}{*}{$\frac{\text { Sampling Location }}{\text { Guard-House (Site II) }}$} & \multicolumn{2}{|c|}{ Taxa } & \multirow{2}{*}{\multicolumn{2}{|c|}{$\begin{array}{c}\text { Rock } \\
(\mathrm{CFU} / 50 \mathrm{~g})\end{array}$}} \\
\hline & Name & Percent & & \\
\hline Guard-House (Site II) & $\begin{array}{l}\text { Aspergillus niger group } \\
\text { Mucor } \text { spp. } \\
\text { Penicillium chrysogenum } \\
\text { Sclerotinia sclerotiorum }\end{array}$ & $\begin{array}{r}55.7 \\
28.6 \\
7.5 \\
8.3\end{array}$ & $\begin{array}{r}76.0 \\
39.0 \\
10.2 \\
11.3 \\
136.5\end{array}$ & $\begin{array}{l}\mathrm{a} \\
\mathrm{b} \\
\mathrm{c} \\
\mathrm{c} \\
\mathrm{C}\end{array}$ \\
\hline Crossroads (Site III) & $\begin{array}{l}\text { Aspergillus niger group } \\
\text { Cladosporium cladosporioides } \\
\text { Mucor spp. } \\
\text { Rhizopus spp. }\end{array}$ & $\begin{array}{r}62.8 \\
3.1 \\
24.1 \\
10.0\end{array}$ & $\begin{array}{r}104.2 \\
5.1 \\
40.0 \\
16.5 \\
165.8\end{array}$ & $\begin{array}{l}a \\
d \\
b \\
c \\
B\end{array}$ \\
\hline $\begin{array}{l}\text { Ventilation Shaft with } \\
\text { Waterfall (Site IV) }\end{array}$ & $\begin{array}{l}\text { Aspergillus niger group } \\
\text { Cladosporium cladosporioides } \\
\text { Mucor spp. } \\
\text { Penicillium chrysogenum }\end{array}$ & $\begin{array}{r}4.3 \\
17.3 \\
26.2 \\
52.3\end{array}$ & $\begin{array}{r}16.3 \\
66.0 \\
100.0 \\
200.0 \\
382.3\end{array}$ & $\begin{array}{l}\mathrm{d} \\
\mathrm{c} \\
\mathrm{b} \\
\mathrm{a} \\
\mathrm{A}\end{array}$ \\
\hline
\end{tabular}

For each location, concentrations followed by the same letter are not statistically different at the $\alpha \leq 0.05$ level according to Fisher's least-significant-difference test; others are. Small letters mark the effect of locations on isolates taxa fungi. Capital letters mark the effect of a particular location on total fungal isolates. 


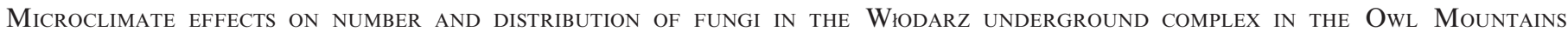
(Góry Sowie), Poland

external environment was Cladosporium, whereas the spores most widely represented inside the cave belonged to Aspergillus and Penicillium. According to other authors, the most abundant fungal taxa isolated from rocks, especially from granite, were from the family Mucorales, and the genera Penicillium, Phoma, Auerobasidium, and Trichoderma (Hirsch et al., 1995; Burford et al., 2003 a,b; Brunner et al., 2011). Our results show statistical differences in the numbers of fungi isolated from the rocks, and the most abundant fungi cultured from granite inside the Włodarz complex were the Aspergillus niger group from Sites I and II and Cladosporium cladosporioides from rock walls and Penicillium chrysogenum from rock debris from Site IV. High concentrations of Cladosporium spp. on the walls at the ventilation shaft are probably caused by the movements of air and water from the outside into the complex there. The ventilation shaft provides a constant bidirectional exchange of air from the external environment that was dominated fungi of the genus Cladosporium.

During the present study, the humidity of the air and the rock moisture inside and outside the complex were conducive for the survival and development of fungi. The air temperature outside, but not inside, was favorable to their development. Krzysztofik (1992) reported that the most important factors affecting the survival of fungi in the environment are temperature and humidity. Nevertheless, that author had observed that the incidence of fungi in the investigated shafts had been dependent on airflow. This is consistent with the numbers of fungi cultured from the air inside our complex and from rocks there. The most fungi were isolated from locations with air movement, including an interior one connected with the external environment.

The high concentrations of carbon dioxide inside the complex may be brought about by tourists or bats or by fungi that decompose organic matter. Hoyos et al. (1998) reported that opening a cave to tourists can result in changes in its microclimatic conditions and the food web, as the mass of visitors increases the cave temperature, $\mathrm{CO}_{2}$ concentration, and the amount of water vapor in the cave's atmosphere. As the Włodarz underground complex is fairly popular for tourist visits, the possible influence of visitors on the conditions in the cave seems quite likely to affect the fungal populations hosted by it. Although Wells and Uota (1970) report that some fungi species decrease in abundance where the highest values of carbon dioxide are observed, it appears that in some situations higher carbon dioxide concentrations may stimulate fungi to more intensive growth.

\section{Conclusions}

Mycobiota of the artificial underground are generally similar to those of natural caves. The internal microclimate and the air flow in adits produce statistically distinct concentrations and species compositions of filamentous fungi in them. Most fungi in the Włodarz underground complex occur in places where they may have migrated from the external environment due to air flow. The most frequently cultured fungi from the air outside and inside the complex were Cladosporium spp. The Aspergillus niger group were most commonly found on the rocks walls and rock debris except for one location, where Penicillium chrysogenum was the species most often isolated from the bottom substrate rocks and $C$. cladosporioides from the rock walls. The incidence level of the fungi isolated from internal air of the adit constitutes no threat to the health of the visiting tourists, though it may be problematic due to possible effects on historical objects like mining trolleys or uniforms. Therefore, it seems that speleomycological research and monitoring are not only important for the underground ecosystems themselves, but also for protection of historical memorabilia.

\section{AcKNowledgements}

We thank the Management Staff of Włodarz complex for their permitting our research in the Włodarz underground complex.

\section{REFERENCES}

Adamski, Z., Henke, K., Zawirska, A., and Kubisiak-Rzepczyk, H., 2008, Grzybice narzadowe (Fungal infections of the organs), in Baran, E., ed., Mykologia - co nowego? (Mycology-What's New?), Wrocław, Cornetis, p. 189-202.

Arx, J.A. von., 1974, The Genera of Fungi Sporulating in Pure Culture, Berlin, J. Cramer, $315 \mathrm{p}$

Brunner, I., Plötze, M., Rieder, S., Zumsteg, A., Furrer, G., and Frey, B., 2011, Pioneering fungi from the Damma glacier forefield in the Swiss Alps can promote granite weathering: Geobiology, v. 9, p. 266-279. doi:10.1111/j.1472-4669.2011.00274.x.

Burford, E.P., Fomina, M., and Gadd, G.M., 2003a, Fungal involvement in bioweathering and biotransformation of rocks and minerals: Mineralogical Magazine, v. 67, p. 1127-1155. doi:10.1180/0026461036760154.

Burford, E.P., Kierans, M., and Gadd, G.M., 2003b, Geomycology: fungi in mineral substrata: Mycologist, v. 17, no. 3, p. 98-107. doi:10.1017/ S0269915X03003112.

Docampo, S., Trigo, M.M., Recio, M., Melgar, M., Garcia-Sanchez, J., and Cabezudo, B., 2011, Fungal spore content of the atmosphere of the Cave of Nerja (southern Spain): diversity and origin: Science of the Total Environment, v. 409, p. 835-843. doi:10.1016/j.scitotenv.2010.10.048.

Ellis, M.B., 1971, Dematiaceous Hyphomycetes: Kew, Surrey, Commonwealth Mycological Institute, 608 p.

Fernández-Cortés, A., Cuezva, S., Sánchez-Moral, S., Cañaveras, J.C., Porca, E., Jurado, V., Martin-Sánchez, P.M., and Saíz-Jiménez, C., 2011, Detection of human-induced environmental disturbances in a show cave: Environmental Science and Pollution Research, v. 18, p. 1037-1045. doi:10.1007/s11356-011-0513-5.

Gu, Ji-Dong, Ford, T.E., Berke, N.S., and Mitchell, R., 1998, Biodeterioration of concrete by the fungus Fusarium: International Biodeterioration and Biodegradation, v. 41, p. 101-109. doi:10.1016/ S0964-8305(98)00034-1.

Hirsch, P., Eckhardt, F.E.W., and Palmer, R.J. Jr., 1995, Fungi active in weathering of rock and stone monuments: Canadian Journal of Botany, v. 72, no. S1, p. 1384-1390. doi:10.1139/b95-401.

Hoyos, M., Soler, V., Canãveras, J.C., Sánchez-Moral, S., and SanzRubio, E., 1998, Microclimatic characterization of a karstic cave: human impact on microenvironmental parameters of a prehistoric rock art cave (Candamo Cave, northern Spain): Environmental Geology, v. 33, p. 231-242. doi:10.1007/s002540050242. 
Hsu, Minna J., and Agoramoorthy, G., 2001, Occurrence and diversity of thermophilous soil microfungi in forest and cave ecosystems of Taiwan: Fungal Diversity, v. 7, p. 27-33.

Kasza, D., 2012, Możliwosci wykorzystania aplikacji GIS do prac związanych z kartowaniem geologicznym na przykładzie podziemnego obiektu "Włodarz" w Górach Sowich: Prace Naukowe Instytutu Górnictwa Politechniki Wrocławskiej, no. 135, p. 23-35. doi:10.5277/ gig121802.

Krzysztofik, B., 1992, Mikrobiologia powietrza, Warsaw, Wydawnictwa Politechniki Warszawskiej, Warsaw, 198 p.

Kuzmina, L.Y., Galimzianova, N.F., Abdullin, S.R., and Ryabova, A.S., 2012, Microbiota of the Kinderlinskaya Cave (South Urals, Russia): Microbiology, v. 81, no. 2, p. 251-258. doi:10.1134/S0026261712010109.

Li, Xianshu, Arai, H., Shimoda, I., Kuraishi, H., and Katayama, Y., 2008, Enumeration of sulfur-oxidizing microorganisms on deteriorating stone of the Angkor monuments Cambodia: Microbes and Environments, v. 23, p. 293-298. doi:10.1064/jsme2.ME08521.

Martini, A., 1963, Yeasts in cavern environments: Archiv für Mikrobiologie, v. 45, p. 111-114. doi:10.1007/BF00408431.

Mulec, J., 2008, Microorganisms in hypogeon: examples from Slovenian karst caves: Acta Carsologica, v. 37, no. 1, p. 153-160.

Mulec, J., Vaupotič, J., and Walochnik, J., 2012, Prokaryotic and eukaryotic airborne micoorganisms as tracers of microclimatic changes in the underground (Postojna Cave, Slovenia): Microbial Ecology, v. 64, p. 654-667. doi:10.1007/s00248-012-0059-1.

Nieves-Rivera, Á.M., 2003, Mycological survey of Rio Camuy Caves Park, Puerto Rico: Journal of Cave and Karst Studies, v. 65, no. 1, p. $23-28$.

Nováková, A., 2009, Microscopic fungi isolated from the Domica Cave system (Slovak Karst National Park, Slovakia). A review: Interna- tional Journal of Speleology, v. 38, p. 71-82. doi:10.5038/1827806X.38.1.8.

Ogórek, R., Lejman, A., and Matkowski, K., 2013, Fungi isolated from Niedźwiedzia Cave in Kletno (Lower Silesia, Poland): International Journal of Speleology, v. 42, p. 161-166. doi:10.5038/1827-806X. 42.2.9.

Porca, E., Jurado, V., Martin-Sanchez, P.M., Hermosin, B., Bastian, F., Alabouvette, C., and Saiz-Jimenez, C., 2011, Aerobiology: an ecological indicator for early detection and control of fungal outbreaks in caves: Ecological Indicators, v. 11, p. 1594-1598. doi:10.1016/j.ecolind.2011.04.003.

Raper, K.B., and Fennell, D.I., 1965, The Genus Aspergillus: Baltimore, Williams and Wilkins Company, 686 p.

Raper, K.B., and Thom, C., 1968, A Manual of the Penicillia: New York, Hafner Publishing Company, 876 p.

Saíz-Jiménez, C., 2012, Microbiological and environmental issues in show caves: World Journal of Microbiology and Biotechnology, v. 28, no. 7, p. 2453-2464. doi:10.1007/s11274-012-1070-x.

Shapiro, J., and Pringle, A., 2010, Anthropogenic influences on the diversity of fungi isolated from caves in Kentucky and Tennessee: American Midland Naturalist, v. 163, no. 1, p. 76-86. doi:10.1674/ 0003-0031-163.1.76.

Vanderwolf, K.J., Malloch, D., McAlpine, D.F., and Forbes, G.J., 2013, A world review of fungi, yeasts, and slime molds in caves: International Journal of Speleology, v. 42, no. 1, p. 77-96. doi:10.5038/1827-806X.42.1.9.

Wells, J.M., and Uota, M., 1970, Germination and growth of five fungi in low-oxygen and high-carbon dioxide atmospheres: Phytopathology, v. 60 , no. 1 , p. $50-53$. doi:10.1094/Phyto-60-50.

Zycha, H., Siepmann, R., and Linnemann, G., 1973, Keys to the Families, Genera and Species of the Mucorales: Berlin, J. Cramer, 49 p. 